\title{
The Xenophobic Tourist
}

Kock, Florian; Josiassen, Alexander; Assaf, A. George

Document Version

Accepted author manuscript

Published in:

Annals of Tourism Research

DOI:

10.1016/j.annals.2018.11.005

Publication date:

2019

License

CC BY-NC-ND

Citation for published version (APA):

Kock, F., Josiassen, A., \& Assaf, A. G. (2019). The Xenophobic Tourist. Annals of Tourism Research, 74, 155166. https://doi.org/10.1016/j.annals.2018.11.005

Link to publication in CBS Research Portal

\section{General rights}

Copyright and moral rights for the publications made accessible in the public portal are retained by the authors and/or other copyright owners and it is a condition of accessing publications that users recognise and abide by the legal requirements associated with these rights.

Take down policy

If you believe that this document breaches copyright please contact us (research.lib@cbs.dk) providing details, and we will remove access to the work immediately and investigate your claim. 


\section{The Kenophobic Tourist \\ Florian Kock, Alexander Josiassen, and A. George Assaf}

Journal article (Accepted manuscript*)

\section{Please cite this article as:}

Kock, F., Josiassen, A., \& Assaf, A. G. (2019). The Xenophobic Tourist. Annals of Tourism Research, 74, 155 166. https://doi.org/10.1016/j.annals.2018.11.005

DOI: 10.1016/j.annals.2018.11.005

* This version of the article has been accepted for publication and undergone full peer review but has not been through the copyediting, typesetting, pagination and proofreading process, which may lead to differences between this version and the publisher's final version AKA Version of Record.

Uploaded to CBS Research Portal: July 2019

(C) 2019. This manuscript version is made available under the CC-BY-NC-ND 4.0 license

http://creativecommons.org/licenses/by-nc-nd/4.0/ 


\section{THE XENOPHOBIC TOURIST}

Annals of Tourism Research, 74, 155-166, 2019

Florian Kock ${ }^{1, \text { corresponding author }}$

Assistant Professor

${ }^{1}$ Copenhagen Business School, Department of Marketing, Solbjerg Plads 3, 2000

Frederiksberg, Denmark

fk.marktg@cbs.dk

$+4538152126$

Alexander Josiassen ${ }^{1}$

Professor

aj.marktg@cbs.dk

$+4538152159$

A. George Assaf ${ }^{2}$

Associate Professor

${ }^{2}$ Isenberg School of Management, University of Massachusetts Amherst, Flint Lab 209A, 121

Presidents Drive Amherst, MA 01003, United States of America

assaf@isenberg.umass.edu

$+14135451492$ 


\begin{abstract}
Addressing the global rise of xenophobia, the authors provide the first investigation of tourist xenophobia (TXO) and its role in shaping tourist behavior. Drawing on research from evolutionary and social psychology, they define TXO as a tourist's perceptual discomfort and anxiety associated with strangers encountered in foreign destinations. The authors develop a reliable, valid and parsimonious TXO scale, and document its importance empirically. The results show that TXO is an important driver behind many, often neglected, behavioral phenomena, such as tourists' preference for travel-related vaccination, willingness to try local food, preference for group travel, travel insurance and agency-booked travel, willingness to travel and actual travel behavior. The authors conclude by discussing implications of findings for research, practice and policy.
\end{abstract}

Keywords: tourist xenophobia, tourist behavior, tourist psychology, evolutionary psychology. 


\section{INTRODUCTION}

Recent years have witnessed a rise in xenophobic tendencies the world over, exemplified by a resurgence of right-wing and anti-immigrant politics in Europe and the U.S. (The Economist 2015). Likewise, xenophobia was chosen as word of the year in 2016 (Time Magazine), reflecting its deep resonance in the public consciousness. While globalization has brought invaluable benefits for many people around the world, it also spurred coalescence of once disparate cultures, ethnicities and whole countries, causing anxiety and a perceived loss of orientation among some people. In a xenophobic worldview, foreigners are constructed as 'unknown others' who threaten the status quo and should be met with suspicion (Hjerm 1998). Despite a recent uptrend, xenophobia is by no means only a contemporary phenomenon and history provides us with rich examples of discrimination of people because of their foreignness, such as in the Roman Empire (Wedeck 1929).

While the type of xenophobia that most often affects tourist behavior is a subtle skepticism toward foreigners, a more blatant form of xenophobia is also influencing tourism. For example, in 2015 a growing resentment toward foreigners in South-Africa hurt the local tourism industry (Reuters 2015). Xenophobia not only directly affects tourism, but rather provides fertile soil for discriminatory behavior permeating many other aspects of human life. Xenophobia has resulted in the persecution and social exclusion of foreigners, detrimental discrimination of immigrants in health care (Crush and Tawodzera 2014) and judicature (Clermont and Eisenberg 2007), or even war (Faulkner, Schaller, Park and Duncan 2004). Xenophobia is particularly prevalent in contexts where people from different ethnic or cultural backgrounds come together. Tourism is inextricably linked to the mingling of different peoples and encounters of strangers (Glover and Filep 2015), a tendency that has 
only been amplified through globalization and lower travel costs. While this fact predestines tourism to be a particularly prone context for xenophobic mechanisms, and despite xenophobia being the travel barrier that U.S. respondents mention most frequently (MissTravel 2017), no study has investigated this phenomenon.

In this study, we set out to identify and empirically examine the phenomenon of tourist xenophobia (TXO) as a potentially important socio-psychological impediment to tourists' international travel. We define TXO as a tourist's perceptual discomfort and anxiety associated with strangers encountered in foreign destinations. We refer to TXO as a negative out-group bias against foreigners, thereby conceptually anchoring our investigation in intergroup bias research which usefulness for tourism research has been recently highlighted (Chien and Ritchie 2018) and empirically documented (Kock, Josiassen, Assaf, Karpen and Farrelly 2018). Intergroup bias refers to the systematic tendency of an individual to perceive and evaluate social realities as determined by group membership, and the enactment thereof (i.e. positive or negative discrimination of in-group and out-group members) (Hewstone, Rubin and Willis 2002), and is one of the most robust phenomena in human psychology (De Freitas and Cikara 2018). By understanding tourist behavior as a potentially biased phenomenon based on in- and out-group perceptions, we acknowledge Pearce and Stringer's (1991) important notion of viewing tourism as a socio-psychological phenomenon in which "people's tourism behavior will derive from primary or secondary groups to which they belong" (p. 147).

By introducing TXO and empirically testing this phenomenon and its consequences for tourist behavior, we aim to make a timely and much needed contribution to research, management and policy. We draw researchers' attention to an important socio-psychological mechanism, thereby contributing to the recent, yet scarce, attempts to examine intergroup biases in tourist behavior (Chien and Ritchie 2018; Griffith and Sharpley 2012; Kock et al. 
2018a). In particular, by introducing TXO as a negative out-group bias, we complement the tourism ethnocentrism construct recently introduced by Kock et al. (2018a), a positive ingroup bias, and address their call to "investigate negative biases and their potential impact on tourists' and residents' behavior" (p. 10). More broadly, our study goes beyond classical assumptions of rational tourist decision-making and thereby adds to the stream of studies which have comprehensively documented that tourist travel behavior is determined by symbolic reasons (Ekinci and Hosany 2006; Kock et al. 2018a; Moran et al. 2018). Further, the present study also constitutes the first empirical application of an evolutionary psychology lens in tourism research, thereby building on recent conceptual efforts in this area (Crouch 2013; Kock, Josiassen and Assaf 2018b). By doing so, we document that TXO can explain many interesting tourist behaviors, such as vaccination intent and local food avoidance, phenomena that existing research has not fully explained yet.

Our multi-study examination of TXO also provides managers with valuable insights into the travel preferences of xenophobic tourists and their identification. These insights are valuable for designing tailored tourism products for this group. The research reported herein is also relevant to policymakers beyond the tourism realm to whom this study highlights that xenophobia may not always manifest as blatant hate but can conceal itself in seemingly apolitical phenomena such as travel. While national borders become more permeable due to relaxed visa applications and cheaper international travel, our study highlights that there may indeed remain invisible borders in individuals' minds that shape tourism.

\section{INTRODUCING AND CONCEPTUALIZING TOURIST XENOPHOBIA}

Xenophobia is "the denigration of individuals or groups based on perceived differences" (Hjerm 1998, p. 335) and can be explained as a survival relevant mechanism that 
dates back to our ancestors (Öhman and Mineka 2001). Xenophobia has endured centuries as a negative predisposition that reflects the explicit or implicit derogation and isolation of those who are considered as intruders, usurpers and antagonistic 'others'. In human history, foreigners and strangers have often posed threats to an individual's well-being due to territorial fights, competition for resources or the spread of new and dangerous diseases. Indeed, historical criminologists who examined ancestral skull fragments document that cross-tribal homicide has been perhaps the most dangerous threat in ancestral societies (Pinker 2011). While suspicion toward strangers can lead to unseized opportunities (i.e., when an individual decides not to approach a stranger who is indeed not dangerous), this suspicion also at times prevents fatal consequences such as homicide at the hand of foreigners (i.e., when an individual decides not to approach a stranger who is indeed dangerous). As such, while both kinds or error of judgement are possible, the consequences of approaching a dangerous stranger often outweigh the consequences of not approaching a non-dangerous stranger. The preference for avoiding a potentially fatal consequence over omitting a potential benefit has been formalized in error management research (Haselton and Nettle 2006) and is considered a fundamental element of the self-protection motive of humans (Griskevicius and Kenrick 2013).

While xenophobia increased survival fitness in ancient times, it might not be functional, and potentially is even dysfunctional in our contemporary lives because modernday environments greatly deviate from those in ancient times. Accordingly, the mismatch paradigm (Nesse and Williams 2012) suggests that our environment changes much more rapidly than our brains can, thus resulting in the dysfunctionality of once effective behavioral systems. Compared to ancient times in which people lived in groups of up to 200 individuals and only rarely had contact with strangers, our contemporary world exposes us to strangers continuously, particularly when travelling. Addressing recent calls to advance tourism 
research through evolutionary psychology (Kock, Josiassen and Assaf 2018b), we suggest that TXO is a manifestation of people's ultimate motive of evading harm that derives from the various dangers that faced our ancestors. We suggest that TXO, a dysfunctional remnant of evolutionary pressures, may be a particularly pronounced bias in today's globalized tourism realities in which individuals continuously face foreigners and strangers.

We conceptualize TXO as a negative out-group bias and therefore draw on intergroup bias research from social psychology. Intergroup bias is a fundamental element of human psychology (e.g., Balliet, Wu and De Dreu 2014; Hewstone et al. 2002), and well aligned with the principles of evolutionary psychology (Brewer 1999; Mahajan et al. 2011). The label "bias" denotes a judgment or behavior that is unjustifiable in objective terms (e.g., judging a person's character solely on group membership), thereby often constituting the antithesis to the ratio-driven homo economicus. As biases are so pervasive in human behavior, their explanation can greatly benefit from unveiling the ultimate Darwinian purpose behind them (Saad 2017).

Only recently have tourism researchers explicitly recognized the important role of intergroup biases in understanding tourist and resident behavior (Chien and Ritchie 2018; Kock et al. 2018a). Tourism research is a particularly fertile ground for examining intergroup biases because two different groups, tourists and residents, interact at destinations. While not explicitly mentioning intergroup biases, a few studies provide hints on the role of sociopsychological factors in tourist and resident behavior. For example, Griffiths and Sharpley (2012) provide an initial exploratory examination of the role that nationalistic tendencies may play in the relationship between tourists and residents. Chen, Hsu and Li (2018) investigate the attitudes that residents of Hong Kong harbor toward Chinese tourists. While these qualitative studies indicate the importance of biases in tourism, they do not go beyond providing exploratory insights, and they do not apply a psychological lens. Taking a culture 
perspective, Ng, Lee and Soutar (2007) find that greater cultural distance negatively affects visiting intention of tourists, and Thyne, Lawson, and Todd (2006) document that residents are less tolerant toward tourists who are culturally dissimilar. While these studies hint that socio-psychological mechanisms may result in potentially discriminative behavior of tourists or residents, they do not identify nor investigate concrete biases in order to document their roles in tourist behavior.

Applying a quantitative approach and a psychological lens, Kock et al.’s (2018a) introduction of the tourism ethnocentrism (TE) construct constitutes the first formal investigation of an explicit intergroup bias in tourist behavior. TE is defined as an individual's prescriptive beliefs and felt moral obligation to support the domestic tourism economy, and thus manifests as a positive in-group bias. The authors empirically document the existence of TE and its influence on tourists' intention to travel domestically and residents' support of domestic tourism development. Using a similar approach, the present study identifies another important bias, tourist xenophobia, which we conceptualize as a negative out-group bias that tourists harbor toward foreigners. TE and TXO are distinct and not reciprocally related because an inclination to help the in-group, as reflected by TE, does not necessarily imply a negative attitude toward an out-group, as reflected by TXO, and vice versa. While TE and TXO may have complementary effects on tourist behavior, they occur independently and impact behavior for different reasons. This distinction is based on seminal psychology and tourism research which documents that intergroup biases can independently manifest as either favoritism for the in-group or derogation of an out-group (Brewer 1999; Halevy, Bornstein and Sagiv 2008; Kock et al. 2018a; Weisel and Böhm 2015). In addition to enhancing this emerging research stream on tourist biases, the present study also contributes to research efforts that investigate reasons for why tourists choose not to travel. Most prominently, Reisinger and Mavondo (2005) investigate tourists' travel anxiety as a barrier to foreign 
travel, however, their unit of analysis is the act of travelling itself and their focus is on examining drivers of travel anxiety. The present study enhances these research efforts by suggesting TXO as another important barrier to international travel.

TXO is a negative out-group bias toward foreigners or strangers because of their perceived 'otherness'. While existing tourism research has mentioned the importance of experiencing 'otherness' and strangers when travelling (Mak, Lumbers and Eves 2012), no study has examined the phenomenon of xenophobia as tourists experience it when travelling. In order to gain an initial understanding of the potential existence of a xenophobic travel predisposition, and how it manifests in tourists' minds, we conducted 15 interviews in rural areas of Germany and the U.S. as an exploratory pre-study. We asked the informants about potential encounters with foreigners when holidaying abroad. The interviews provide initial exploratory indication of the existence of TXO and its potential to impact tourists' avoidance of foreign destinations; exemplary statements are shown in Table 1. In particular, a xenophobic tourist (1) anticipates discomfort when interacting with 'strangers', (2) ascribes an alleged ill-will to these foreigners, (3) perceives her- or himself as a potentially vulnerable outsider when travelling abroad, and (4) shows an inclination to either avoid foreigners and foreign destinations entirely or at least face them with suspicion and reservation. These preliminary observations indicate important facets of out-group biases that have also been identified by social psychology. In conclusion, our conceptual foundation and the supporting exploratory evidence of our pre-study motivate us to develop a conceptual model of TXO which is capable of revealing the role xenophobia plays in tourist behavior.

\section{Exemplary statements}

"Encountering locals makes me often uncomfortable; I don't understand what they say and I feel like an outsider." (R1)

"I tried to avoid contact with locals when abroad; it makes me uneasy to interact with them." (R4) 


\begin{tabular}{|l|}
\hline "Last time, a local approached me on the street. I ignored him, you \\
never know whether they want to trick you." (R7) \\
\hline "I don't travel abroad anymore, I don't like the people there or their \\
customs." (R8) \\
"I am anxious when interacting with people abroad, there may easily \\
be misunderstandings, so I try to ignore them."(R12) \\
"The residents at foreign destinations try to exploit tourists like me; I \\
am always very careful and attentive." (R15) \\
\hline
\end{tabular}

Table 1: Statements yielded by the interviews

\section{CONCEPTUAL FRAMEWORK AND HYPOTHESES}

Psychologists document that intergroup biases do not exist for their own sake but serve adaptive functions for the individual who holds them (Durante and Griskevicius 2018). Explaining biases based on their adaptive functions connotes to study them at the ultimate motives level. Studying phenomena at the ultimate motives level, instead of only the proximate motives level, resembles Tinbergen's (1963) seminal taxonomy on explanations and is fundamental to evolutionary psychology thinking. While most studies executed in psychology, marketing, management and tourism research rely on proximate motives to explain phenomena (see Kock et al. $2018 \mathrm{~b}$ for a recent account of evolutionary psychology in tourism research), we rely on ultimate motives to develop our conceptual framework and hypotheses. As already outlined, the ultimate motive of TXO is to avoid harmful consequences, while the motive of TE is affiliation (cf. Kock et al. 2018b).

We put forward that the ultimate motive of TXO translates into tourist behavior through the coping mechanisms that derive from perceived intergroup threats. This view derives from threat-based approaches on intergroup bias (Riek, Mania and Gaertner 2006) according to which individuals perceive out-groups to pose threats and, as a consequence, engage in coping behavior to alleviate those threats (Cottrell and Neuberg 2005). Accordingly, xenophobic tourists perceive foreigners to pose threats (such as the threat of 
being exploited; see Table 1) and react toward these threats with different coping behaviors. It is these coping behaviors that we hypothesize in our TXO framework (Figure 1).

TXO is a negative out-group bias that manifests in tourists' anticipated or actual discomfort and anxiety associated with strangers encountered at foreign destinations. The ultimate function of this bias is evading harm and a suitable way of doing so is by staying away from those foreigners that possibly pose threats. We hypothesize that tourists high on TXO are less willing to travel to foreign destinations in order to cope with the perceived threats. Importantly, while evolution predisposed people to avoid physical harm from strangers that pose realistic threats, the evading harm motive can be extended to symbolic threats posed by strangers (Cottrell and Neuberg 2005; Riek et al. 2006; Scheepers, Spears, Dosje and Manstead 2006), such as the confrontation with conflicting values (e.g., the treatment of animals or the role of women in other countries) or strange customs and sights (e.g., the burka in Muslim countries or the sexual liberty in Western countries). While symbolic threats do not pose immediate harm to the physical self, they threaten the cultural integrity and disconfirm the identity of the xenophobe when she or he is abroad. In this research, we do not only examine the effect of TXO on intentions but also on actual behavior because tourism researchers (e.g., Juvan and Dolnicar 2014) highlight the potential gap between behavioral intentions and actual behavior. Thus, we test whether TXO influences tourists' actual travel behavior, mediated by intentions.

Hypothesis 1: Tourist xenophobia has a negative effect on tourists' willingness to engage in foreign tourism.

Hypothesis 2: Tourists' willingness to engage in foreign tourism has a positive effect on tourists' trips to foreign destinations. 
A related, yet distinct motive that evolutionary psychologists have ascribed to xenophobia is disease avoidance (Schaller and Park 2011). Infectious diseases have been a major threat throughout human history (Wolfe, Dunavan and Diamond 2007), often greatly decimating populations. For example, up to $75 \%$ of the native North American population was wiped out by pathogens brought over by European settlers (Dobson and Carter 1996). As this example indicates, diseases have often spread with contact to strangers or unknown tribes, thus leading individuals to develop, in addition to a physical immune system, a behavioral immune system that minimizes pathogen transmission. Xenophobia is such a behavioural immune system and its existence has been supported across multiple studies (Faulkner et al. 2004; Navarrete and Fessler 2006).

Tourists' disease avoidance and perceived pathogen threat are recurring topics in the tourism literature (Jonas, Mansfeld, Paz and Potasman 2010; Lepp and Gibson 2003; Rittichainuwat and Chakraborty 2009), however, existing research is inconsistent on whether tourists' concern with travel-related diseases impacts their intention to travel (Reisinger and Mavondo 2005; Sönmez and Graefe 1998) or not (Lee, Song, Bendle, Kim and Han 2012). Importantly, existing studies document individual differences of tourists' disease avoidance propensity (Chien, Sharifpour, Ritchie, Watson 2017; Hajibaba, Gretzel, Leisch and Dolnicar 2015). TXO can inform this research on disease avoidance by explaining why some tourists may be more prone to experience a contamination threat, and consequently have a higher propensity for travel-related vaccination. We suggest that disease avoidance is a fundamental motive underlying TXO, stemming from the evolutionary pathogen threat posed by foreigners. Specifically, foreigners may be perceived to violate customs that serve as barriers against the transmission of disease, such as cultural norms pertaining to hygiene and food preparation. A common means to avoid diseases while travelling is vaccination and we 
therefore suggest that a xenophobic tourist is more likely to get a vaccination before foreign travel.

Hypothesis 3: Tourist xenophobia has a positive effect on tourists' preference for travelrelated vaccination.

Through the motive of disease avoidance, TXO can also contribute to the understanding of another important research area in tourism: food consumption. Tourism researchers have devoted significant efforts to understand tourists' food preferences when travelling abroad. Tourists spend up to one-third of their travel budget on food, and the local cuisine can be an important driver of destination choice (Mak et al. 2012). Existing research is, however, scattered and ambiguous regarding local food preference, with some researchers supposing that tourists should be eager to try unknown local cuisines (e.g., Chang, Kivela and Mak 2010) and others suggesting that tourists avoid local food (e.g., Cohen and Avieli 2004). We suggest that xenophobia helps explain individual differences in tourists' aversion to local foods, with more xenophobic tourists being less likely to partake. This view corresponds with the recurring associative link between what is foreign and a perceived threat of contamination (Cottrell and Neuberg 2005). From an evolutionary perspective, the intake of unknown foods is a vital health risk, and the avoidance thereof a way to inhibit the ingestion of harmful agents. We suggest that this evolutionary remnant manifests in the culinary behavior of contemporary tourists.

Hypothesis 4: Tourist xenophobia has a negative effect on tourists' intention to try local food.

According to our conceptualization of TXO and the conducted interviews, xenophobic tourists are uncomfortable with and perceive foreigners who they encounter at foreign destinations as being suspicious. This perception in conjunction with a self-image of being a temporary 'outsider' in a foreign place (Griffiths and Sharpley 2012) may elicit a perception 
of vulnerability (Navarrete and Fessler 2006) and high travel risk. We suggest that this perception of vulnerability results in at least two coping mechanisms that allow tourists to alleviate this psychological state. First, we argue that xenophobic tourists have a higher propensity to book travel insurance. On first sight, taking out travel insurance cannot rationally externalize the risks and threats associated with encountering foreigners at destinations. However, on second sight, taking out insurance provides the tourist with a halo effect of security that can counter the perceived vulnerability and lowers risk perceptions (Chen, Kalra and Sun 2009). In other words, travel insurance lowers the xenophobe's perceived travel risk and induces peace of mind, consequently providing a feeling of security which can diminish the perceived vulnerability elicited by foreigners.

Second, we suggest that TXO increases tourists' preference for travel in groups because group travel can represent a coping strategy for both realistic and symbolic threats. Travelling with other members of the in-group addresses the 'strength-in-numbers' mechanism and decreases perceived vulnerability (Brewer 1999), thereby constituting a means to cope with realistic threats. This notion is supported by existing research which documents that xenophobic predispositions and perceived threats posed by foreigners increase people's need for teaming up with fellow in-group members (Scheepers et al. 2006), consequently addressing people's ultimate motive of affiliation (Kock et al. 2018b). In addition, we suggest that group travel with fellow citizens also reassures the xenophobic tourist of her or his constituent identity despite the foreign social environment, thus representing a means to cope with symbolic threats. This argument is supported by tourism research which has observed that nationalistic tourists seek unity with fellow tourists when being abroad (Griffiths and Sharpley 2012). Following the same line of thought, we also suggest that TXO relates positively to tourists' intention to book a holiday abroad through a travel agency. Travel agencies can serve as trustworthy intermediaries (Moliner, Sanchez, 
Rodriguez and Callarisa 2007) between the tourist and the foreign destination, and potentially lower the risk that tourists associate with the travel (Money and Crotts 2003).

Hypothesis 5: Tourist xenophobia has a positive effect on tourists' intention to book travel insurance.

Hypothesis 6: Tourist xenophobia has a positive effect on tourists' preference for group travel.

Hypothesis 7: Tourist xenophobia has a positive effect on tourists' preference for booking through a travel agency.

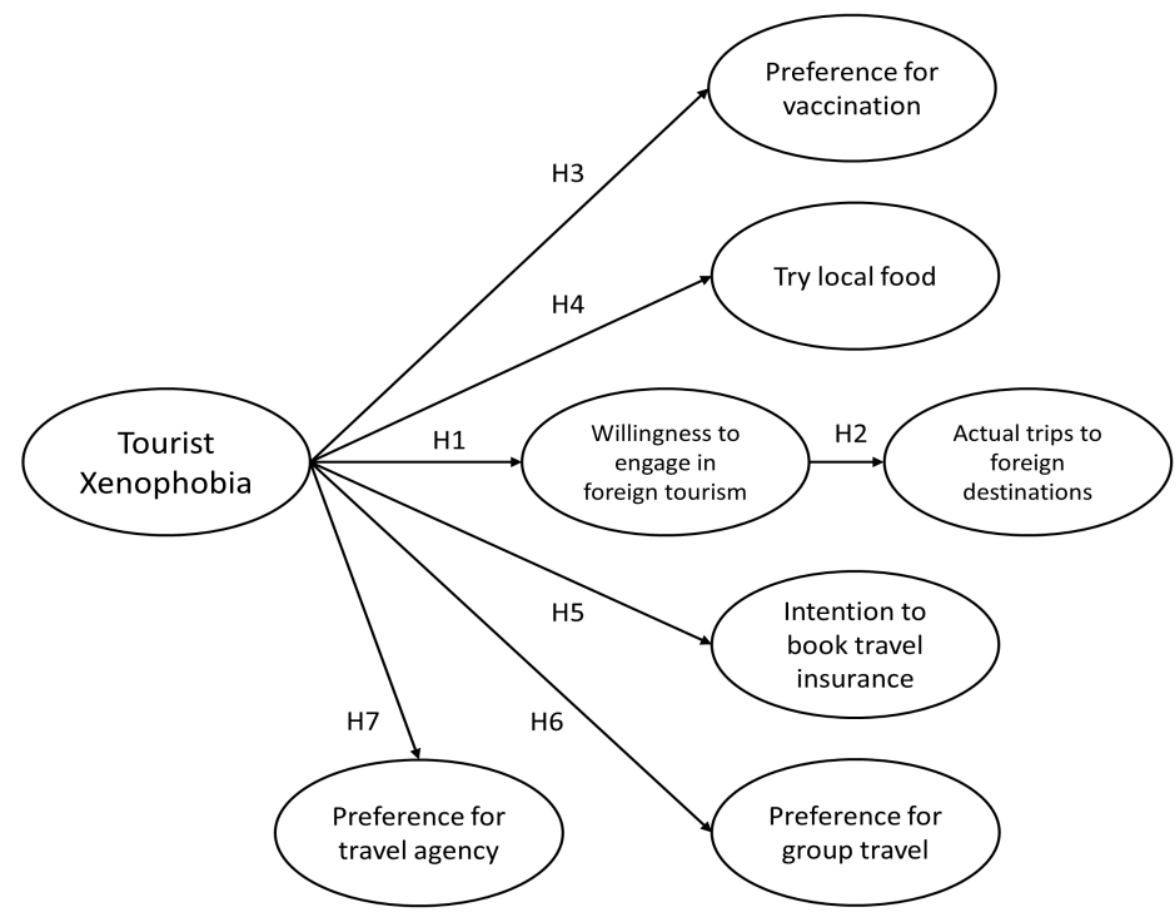

Figure 1: The TXO framework

\section{STUDY 1: SCALE DEVELOPMENT}

The development of a tourist xenophobia scale is necessary for two reasons. First, no measure exists that can capture the psychological phenomenon we have identified and seek to 
investigate. While psychology research is generally scarce on examinations of xenophobia, those who investigate xenophobia focus on attitudes toward immigrants, and therefore correspond with recent media interpretations of xenophobia. However, a focus on immigrants is not suitable in the tourism context because it is the traveler her- or himself who perceives residents in foreign destinations as the object of xenophobia. Second, no valid operationalization exists for the phenomenon of xenophobia in the extant literature, requiring the development of a scale from scratch. It is for this second reason that we believe to also make a contribution to research beyond the tourism discipline.

For the development of items, we followed a combination of inductive and deductive methods (Hinkin 1995). Following established scale development procedures (e.g., Kock et al. 2018a; Ouellet 2007), we generated an initial item pool for TXO by conducting exploratory interviews with 21 individuals and reviewing existing psychology literature on xenophobia and intergroup bias (e.g., Cottrell and Neuberg 2005; Faulkner et al. 2004; Hjerm 1998; Riek et al. 2006). We recruited potential informants through a two-staged streetintercept procedure (Ouellet 2007) in a mid-sized city in the Midwest of the U.S. First, we asked the approached individuals to fill out a brief screening questionnaire that contained three 7-point Likert items reflecting a generic xenophobic attitude and that were informed by the existing intergroup bias literature ('Interacting with foreigners makes me uneasy', 'Foreigners should not be trusted' and 'I try to avoid contact with foreigners'). We determined the individuals' xenophobia levels according to a cut-off of 3 out of 7 (Ouellet 2007) on the xenophobia measure, and only interviewed those who scored 3 or higher. Of the 42 approached informants, 23 qualified for the interview of which 21 agreed to take part in (demographics of the informants are shown in Table 2). We selected the U.S. because it is the biggest outbound tourism market by number of tourists and the second biggest by international tourism expenditure (UNWTO 2017). Because TXO is hypothesized to 
particularly affect outbound tourism, we deem the U.S. an appropriate context for this study. In order to understand how TXO might manifest in the minds of tourists, we asked the prequalified informants to describe beliefs about, and potential or actual experiences with residents in foreign destinations in an open-ended approach (Kock et al. 2018a). When a negative belief or incident was stated, we followed up on it ('Can you please explain this statement?') in order to understand whether the informant engaged in stereotypical interpretations of the foreigners and encounters with them. This procedure yielded an initial pool of 31 items.

\begin{tabular}{|l|c|c|c|c|}
\hline Sample & $\begin{array}{c}\text { Exploratory } \\
\text { Pre-Study }\end{array}$ & $\begin{array}{c}\text { Study 1: } \\
\text { Qualitative }\end{array}$ & $\begin{array}{c}\text { Study 1: } \\
\text { Quantitative }\end{array}$ & $\begin{array}{c}\text { Study 2: } \\
\text { Quantitative }\end{array}$ \\
\hline Sample size & 15 & 21 & 429 & 417 \\
\hline Age (\%) & & & & \\
\hline$>30$ years & 33.3 & 33.3 & 32.1 & 25.7 \\
\hline $30-49$ years & 40.0 & 28.6 & 36.6 & 51.2 \\
\hline$<49$ years & 26.7 & 38.1 & 31.3 & 23.1 \\
\hline Gender (\%) & & & & \\
\hline Female & 46.7 & 57 & 55.9 & 53.5 \\
\hline Male & 53.3 & 43 & 44.1 & 46.5 \\
\hline Education (\%) & & & & \\
\hline $\begin{array}{l}\text { Finished a master's degree or } \\
\text { higher }\end{array}$ & & & 17.0 & 15.1 \\
\hline Finished a bachelor's degree & & & 43.1 & 44.6 \\
\hline Enrolled at university & & & 17.7 & 18.2 \\
\hline Finished secondary school & & & 17.3 & 19.7 \\
\hline Finished primary school & & & 4.9 & 2.4 \\
\hline
\end{tabular}

Table 2: Sample characteristics

In order to arrive at a manageable number of items for our questionnaire, we followed established scale development procedures (Josiassen 2011). We judged all items for potential item redundancy and dropped nine duplicate items. We then evaluated the remaining items in order to ensure content and face validity by asking three tourism and marketing researchers to judge the items with regard to how well they reflect the full content of TXO (assessment of content validity) and how well they capture the intended construct and not another construct 
(assessment of face validity). This step resulted in the elimination of another 12 items, leaving a total of 10 items for the statistical analysis.

In order to further reduce the number of items and empirically test the scale's reliability and convergent validity, we designed questionnaires containing the TXO items, followed by behavioral intention variables and several classificatory questions. Because of the potentially sensitive nature of TXO, we tested for respondents' tendency to provide social desirable answers and included items from the social desirability bias scale (Crowne and Marlowe 1960) in the beginning of the questionnaire, along with the information that the anonymity of respondents was assured. The four items, measured on 7-point Likert scales, are: 'Before voting I thoroughly investigate the qualifications of all the candidates'; 'I have never intensely disliked anyone'; 'When I don't know something I don't at all mind admitting it'. This questionnaire was then administered to a sample of U.S. respondents recruited from the Mechanical Turk (MTurk) online panel. Crowdsourcing online panels such as MTurk provide access to a large number of relatively diverse respondents and have been found to be of equal or higher data quality than street intercepts and student samples (Goodman and Paolacci 2017). However, as in any other form of questionnaire-based data collection, a few respondents may engage in satisficing, straight-lining or other biasing response behavior (e.g., Barber and Barnes 2013). Such behavior can be effectively detected and alleviated by the use of instructional manipulation checks (IMC; Paas, Dolnicar and Karlsson 2018). One IMC item ('Please select agree as the answer here'; similar answer format as the other variables) was interspersed throughout the questionnaire, and respondents who provided a wrong answer to it (27 respondents; $5.9 \%$ of total respondents) were deleted from the sample. Respondents were also informed about the use of IMCs before accessing the questionnaire in order to deter satisficing. After cleaning for IMC violation, we obtained completed questionnaires from 429 respondents. The sample characteristics are shown in Table 2. 
We conducted an exploratory factor analysis on the TXO items which met both the Kaiser-Meyer-Olkin (KMO) criterion and Bartlett's test of sphericity (BTS) $(\mathrm{KMO}=.881$; $\mathrm{BTS}=1723.506 ;$ d.f. $=28, \mathrm{p}<.001)$. In order to determine how many factors to retain, we conducted a parallel analysis (Horn 1965) since the heavily used Kaiser-Guttman criterion (i.e., the retention of factors with eigenvalues greater than 1.00) is often inaccurate in identifying the correct number of factors (Lance, Butts and Michels 2006). The parallel analysis yielded one factor, in support of our contention that TXO is a unidimensional construct.

We then evaluated all items consecutively along four criteria. First, we scrutinized factor loadings and item-to-total correlations sequentially, using .4 and .5 as the critical thresholds. Second, very high inter-item correlations indicated item redundancy, resulting in the deletion of one item. Third, for each item, we tested whether its deletion would increase the composite reliability of the scale. Because these three steps did not provide enough indication as to which items to delete in a psychometrically acceptable scale, we applied an iterated $\chi^{2}$-difference test procedure (Kock et al. 2018a) to eliminate further items and purify the scale. We selected and deleted the item with the lowest item-to-total correlation, stopping only when the $\chi^{2}$-difference test indicated no difference or the adjusted goodness-of-fit index did not increase (Voss, Spangenberg and Grohmann 2003). These four item-elimination steps resulted in the removal of four items, leaving six items in the final TXO scale.

Factor loadings of the six items ranged from .63 to .82 and the explained variation of the extracted factor was .61. The composite reliability (CR) was .90 and the average variance extracted (AVE) was .61, thereby documenting reliability of the scale. In addition, the correlation between the TXO scale and the social desirability measure was not significant, indicating that social desirability bias was not a significant problem. The six items, their parameters, as well as scale parameters are shown in Table 3. In addition, all six TXO items 
met the assumptions of normality with univariate skewness and kurtosis being within -1 and 1.

\begin{tabular}{|c|c|c|c|c|}
\hline Constructs/Items & $\begin{array}{c}\text { Item } \\
\text { Mean }\end{array}$ & $\begin{array}{c}\text { Item } \\
\text { Loadings }\end{array}$ & $\begin{array}{l}\text { Corrected Item-to- } \\
\text { Total Correlation }\end{array}$ & $\begin{array}{c}\text { Scale } \\
\text { parameters }\end{array}$ \\
\hline $\begin{array}{l}\text { 1....I doubt that the locals } \\
\text { would be welcoming to tourists } \\
\text { like me. ('Doubt') }\end{array}$ & 3.08 & .70 & .68 & \\
\hline $\begin{array}{l}\text { 2. ...I would not feel } \\
\text { comfortable in the culture. } \\
\text { ('Comfortable') }\end{array}$ & 3.16 & .68 & .66 & \\
\hline $\begin{array}{l}\text { 3. ...I would probably feel } \\
\text { uneasy to engage with locals } \\
\text { there. ('Uneasy') }\end{array}$ & 3.11 & .70 & .69 & \\
\hline $\begin{array}{l}\text { 4. ...there would be many } \\
\text { misunderstandings between me } \\
\text { and the locals there. } \\
\text { ('Misunderstandings') }\end{array}$ & 3.86 & .63 & .60 & \\
\hline $\begin{array}{l}5 . . . \text { I would be suspicious } \\
\text { toward the locals I encounter } \\
\text { there. ('Suspicious') }\end{array}$ & 3.74 & .82 & .71 & \\
\hline $\begin{array}{l}\text { 6. ...I would be worried that the } \\
\text { locals met me with reservation. } \\
\text { ('Worried') }\end{array}$ & 3.57 & .82 & .71 & \\
\hline Composite reliability (CR) & & & & .90 \\
\hline $\begin{array}{l}\text { Average Variance Extracted } \\
\text { (AVE) }\end{array}$ & & & & .61 \\
\hline $\begin{array}{l}\text { Explained variation of extracted } \\
\text { factor }\end{array}$ & & & & .61 \\
\hline
\end{tabular}

Notes: The items are introduced as 'If I travelled to a foreign country,' and scored on a seven-point Likert scale (1="strongly disagree"; 7="strongly agree").

Table 3: Parameters of the TXO scale

\section{STUDY 2: HYPOTHESES TESTING}

\section{Participants and procedures}

The objective of Study 2 is to examine whether TXO can explain important behavioral phenomena of tourists. Specifically, this study tests the hypotheses one to seven developed in 
the nomological network (Figure 1). Similar to Study 1, we collected data through questionnaires administered to a sample of U.S. respondents on MTurk. Before inviting respondents to the questionnaire, we asked them to answer classificatory questions about their age, gender, income level and travel behavior (Kock et al 2018a). Only respondents that were 18 or older, with sufficient travel funds (annual household income $>\$ 30,000$ ) and who had travelled significant distances before (> 70 miles in the last two years) were forwarded to the questionnaire. Further, we controlled for the IP address of each respondent to ensure that no respondent from Study 1 could participate in this study. We included two IMC questions, the same social desirability items as in Study 1 (Crowne and Marlowe 1960), as well as a marker question ('I prefer savory over sweet food') to test for common method bias (CMB) ex-post (Podsakoff, MacKenzie and Podsakoff 2012). We collected 417 completed questionnaires while another 53 respondents ( $11.3 \%$ of the total sample) were disqualified by the IMC questions.

\section{Measures}

Table 4 shows all scales used in the questionnaire as well as their respective items and psychometric parameters. The questionnaire contained the newly developed TXO scale as well as the measures corresponding to the developed hypotheses one to seven. Tourists' willingness to engage in domestic tourism was measured by adapting the willingness to visit scale from Kock, Josiassen and Assaf (2016). Actual travel behavior was measured by asking respondents to indicate how many holiday trips to foreign destinations they have taken in the last five years. We adapted Kock et al.'s (2016) intention measure of willingness to visit in order to derive intention measures for tourists' intention to receive travel-related vaccination, tourists' intention to try local food, tourists' intention to book travel insurance and tourists' preference for group travel. The adaptation of parsimonious intention scales, which was informed by reviewing relevant existing literature (e.g., Hajibaba, Gretzel, Leisch and 
Dolnicar 2015; Kim and Eves 2012), was necessary because no scales existed for the four previously mentioned behavioral intentions we intended to measure. In addition, we captured respondents' age, gender, education, as well as respondents' political opinion on a republicandemocrat semantic differential scale.

Convergent validity of all multi-item scales was achieved as the standardized factor loadings were significant with the lowest being .68. In addition, all AVE's were above .5 . Composite reliabilities were above .9 , thereby indicating satisfactory levels of reliability (Lance et al. 2006). The discriminant validity of all measures was assessed through both the Fornell-Larcker (1981) criterion and the heterotrait-monotrait (HTMT) ratio criterion. As for the Fornell-Larcker criterion, for all pairs of scales the AVE was higher than the pairwise squared estimated correlation. As for the HTMT ratio criterion, for all scale pairs the ratio of the average of the heterotrait-heteromethod correlations to the average of the monotraitheteromethod correlations ratio was below .85 (Kline 2011). Thus, both heuristics indicate discriminant validity of all scales used in the model. Further, all variance inflation factors were below the critical threshold of 7 , indicating that collinearity was not harmful.

\begin{tabular}{|c|c|c|c|}
\hline Construct/Items & Factor Loadings & CR & AVE \\
\hline $\begin{array}{l}\text { Tourist xenophobia (newly developed) } \\
\text { If I travelled to a foreign country, }\end{array}$ & & .92 & .66 \\
\hline 1....I doubt that the locals would be welcoming to tourists like me. ('Doubt') & .76 & & \\
\hline 2. ...I would not feel comfortable in the culture. ('Comfortable') & .82 & & \\
\hline 3. ...I would probably feel uneasy to engage with locals there. ('Uneasy') & .83 & & \\
\hline $\begin{array}{l}\text { 4. ... There would be many misunderstandings between me and the locals } \\
\text { there. ('Misunderstandings') }\end{array}$ & .68 & & \\
\hline 5. ...I would be suspicious toward the locals I encounter there. ('Suspicious') & .76 & & \\
\hline $\begin{array}{l}\text { 6. ...I would be worried that the locals would meet me with reservation. } \\
\text { ('Worried') }\end{array}$ & .78 & & \\
\hline Willingness to visit (Kock et al. 2016) & & .96 & .89 \\
\hline
\end{tabular}




\begin{tabular}{|c|c|c|c|}
\hline 1. I intend to spend my next holiday at a destination abroad. & .87 & & \\
\hline 2. The next time I go on vacation, I will choose a foreign destination. & .98 & & \\
\hline 3. It is very likely that I would choose a foreign tourist destination. & .89 & & \\
\hline Preference for travel-related vaccination (newly developed) & & .95 & .85 \\
\hline 1. When travelling abroad, I would get a vaccination. & .87 & & \\
\hline 2. Getting a vaccination is a must when travelling abroad. & .97 & & \\
\hline 3. I would feel bad if I travelled to other countries without immunization. & .81 & & \\
\hline Intention to try local food (newly developed) & & .94 & .80 \\
\hline 1. I am curious to try local food that I don't know. & .86 & & \\
\hline 2. When travelling, I like to taste local food. & .91 & & \\
\hline 3. I enjoy local food when travelling. & .93 & & \\
\hline 4. When eating abroad, I prefer the local food alternative. & .73 & & \\
\hline \multicolumn{4}{|l|}{ Intention to book travel insurance (newly developed) } \\
\hline $\begin{array}{l}\text { 1. Imagine you travel abroad, how likely is it that you would book a travel } \\
\text { insurance? }\end{array}$ & - & - & - \\
\hline \multicolumn{4}{|l|}{$\begin{array}{l}\text { Preference for group travel (newly developed) } \\
\text { When travelling abroad, }\end{array}$} \\
\hline 1....I prefer going in groups with people from my home country. & - & - & \\
\hline $\begin{array}{l}\text { Preference for booking through an agency (newly developed) } \\
\text { When travelling abroad, }\end{array}$ & & .97 & .90 \\
\hline 1 ....I prefer to book through an agency which arranges everything. & .94 & & \\
\hline 2. ...I tend to book an organized trip through a travel provider. & .87 & & \\
\hline 3. ...I prefer booking a package through an agency. & .97 & & \\
\hline
\end{tabular}

Table 4: Constructs and their parameters used in Study 2

Results

As a preliminary step, we checked the univariate skewness and kurtosis of the TXO items and found them to be within the limits of -1 and 1 . Further, the social desirability scale was not significantly correlated with other constructs, suggesting that social desirability bias was not an issue in the sample. As for CMB, we allowed all items to load on one latent factor in order to control for the effects of an unmeasured latent factor (i.e., Harman's one-factor test). Comparing item loadings and their significance level of the correlations between the models with and without the latent CMB factor yielded no differences. In addition, the marker 
variable did not significantly correlate with other constructs. Then, the developed model was examined through a covariance-based structural equation modelling approach in AMOS 24. The sample characteristics are listed in Table 2. The obtained data fits the developed model well, as indicated by the goodness of fit indices $\left(\chi^{2} / \mathrm{df}=2.828 ; \mathrm{CFI}=.943 ; \mathrm{NNFI}=.936\right.$; RMSEA $=.066 ;$ SRMR $=.0981)$.

As for the structural model, the results document strong support for our hypotheses, documenting the importance of TXO in explaining tourist destination choice (willingness to visit foreign destinations and actual trips) as well as more distant and less obvious tourist behaviors (Figure 2). First and foremost, TXO has a significant and negative effect on tourists' willingness to travel abroad $(-.12, \mathrm{p}<.05)$ thereby confirming H1. Further, tourists' willingness to travel abroad has a significant and positive effect on tourists' holiday trips to foreign destinations $(.47, \mathrm{p}<.001)$, thereby documenting that TXO shapes actual travel behavior through travel intentions. In addition to this mediating effect, we also tested for a direct effect of TXO on actual behavior but found this effect to be non-significant. The results also document that more xenophobic tourists have a higher propensity to receive travelrelated vaccination $(.27, \mathrm{p}<.001)$ and are less likely to try local food when travelling $(-.32$, $\mathrm{p}<.001)$. Further, higher levels of TXO relate to a higher intention to book travel insurance $(.19, \mathrm{p}<.001)$, to travel in groups $(.34, \mathrm{p}<.001)$ and to book through a tourism agency $(.33$, $\mathrm{p}<.001)$. In summary, $\mathrm{H} 1$ to $\mathrm{H} 7$ are therefore confirmed. 


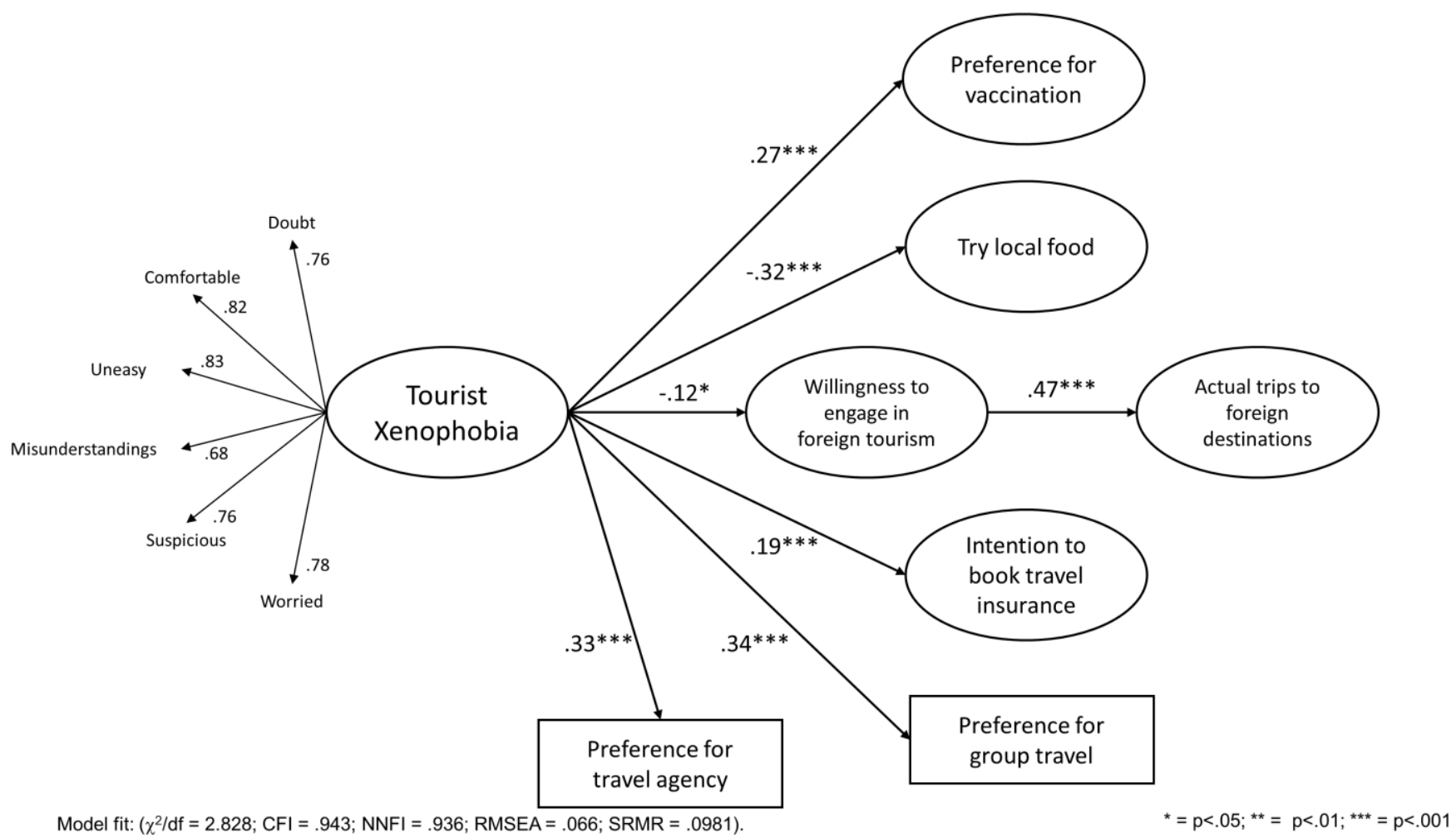

Figure 2: Structural equation modelling results of Study 2

We further examined whether demographic variables relate to TXO, specifically age, gender and education. In addition, we tested whether TXO varies with political opinion. We conducted Kruskal-Wallis $\mathrm{H}$ tests for gender, age and education, and found significantly different levels of TXO for gender $\left(\chi^{2}=6.387, \mathrm{p}<.05\right)$, indicating that male tourists are more xenophobic than female tourists. No significant differences were observed for age and education. As for political opinion, we conducted another Kruskal-Wallis H test and found that Republican voters score significantly higher on TXO than Democrats $\left(\chi^{2}=28.237\right.$ $\mathrm{p}<.01)$ 


\section{CONCLUSION}

Tourism is inextricably linked to the encounter between tourists and residents. When members of two different groups interact, intergroup biases are likely to play an important role. As the world gets smaller due to increased affluence of the travelling middle-class and improvements in technology, interactions between groups increase and xenophobia has become a phenomenon reflective of our current zeitgeist . Against this background, and addressing recent calls for research on intergroup biases in tourism (Chien and Ritchie 2018; Kock et al. 2018a; Pearce and Packer 2013), the present article provides an introduction and investigation of the xenophobia phenomenon in tourism for the first time. The results reveal that TXO contributes significantly to our understanding of tourist behavior. The findings reported herein have profound implications for both researchers and managers who investigate tourists' travel behavior abroad. Because TXO captures a novel phenomenon that has not been researched in the tourism literature before, it is important that researchers add this bias to their future examinations.

In two studies, we identify the important role that tourist xenophobia plays in shaping tourist behavior. We started out by conceptualizing a TXO construct grounded in social and evolutionary psychology and documented anecdotal evidence of its existence and constituent factors in a qualitative pre-study. Subsequently, a reliable, valid and parsimonious TXO scale was developed. The resultant scale was applied to test a number of hypotheses. We find that TXO has a negative impact on tourists' inclination to travel abroad, and even more importantly, an effect on actual travel behavior, thus documenting that TXO matters. Of particular importance is our finding that, albeit xenophobes may travel abroad, their travel behavior is influenced by their level of TXO, and thus may differ from the preferences of other tourists. Our results reveal that important, yet under-researched, tourist behaviors such 
as vaccination intent, group travel preference and local food consumption can be explained through TXO.

Our study advances tourism research in several important ways. First, a fundamental theoretical contribution is that TXO is important to include in future studies when investigating tourists' dispositions toward foreign travel, indicating that the sole reliance on tourists' rational decision-making (such as focusing on tourists' destination image only) is likely to result in an incomplete picture at best. Second, our study advances exploratory research that seeks to understand the role of intergroup phenomena in tourism research (e.g., Chen et al. 2018; Griffiths and Sharpley 2012). It does so by conceptualizing and measuring an explicit socio-psychological bias, tourist xenophobia, and documenting its impact on tourist behavior. Specifically, TXO advances the recently introduced research stream of tourist biases (Kock et al. 2018a). Third, the present paper is also the first to empirically document the usefulness of an evolutionary psychology approach to inform tourism research, thereby addressing recent calls in the literature (Crouch 2013; Kock et al. 2018b). Specifically, both the conceptualization of TXO and the developed model capitalize on evolutionary reasoning, enabling us to hypothesize novel relationships between, at first sight unrelated, phenomena. Importantly, evolutionary psychology also enables us to interpret interesting findings of our studies: The finding that men score significantly higher on TXO than women can be explained through the male-warrior hypothesis according to which males were historically the ones involved in intergroup contact and aggression, and the fight for territory (Vugt, Cremer and Janssen 2007). Thus, xenophobia has served as a survival relevant mechanism for males when interacting with potentially threatening strangers.

Our research also contributes to research beyond the tourism discipline. To the best of our knowledge, we are the first to provide a psychology-based conceptualization and operationalization of xenophobia, thereby constituting a contribution that reaches beyond the 
tourism discipline. While our developed scale focuses on the tourism domain, the conceptualization and measure developed herein can serve as a basis for, for example, psychology, policy and organizational behavior researchers who seek to understand the role of xenophobia in various contexts. Further, we empirically document that a political opinion can manifest in tourist behavior; this finding enhances the burgeoning literature on understanding concealed political manifestations in consumer behavior (Jost 2017). In particular, we find that those whose political opinion tends to be Republican score higher on TXO on average, thus confirming reported psychological differences (Jost 2017) such as a higher preference for security and conformity among conservatives (such as Republicans) compared to liberals (such as Democrats).

For practitioners, providing a conceptualization of TXO allows for the phenomenon to be considered when developing and marketing tourism offerings. For instance, managers of travel agencies can consider xenophobia when strategizing in current or new markets. TXO is also a worthwhile topic for politicians concerned with tourism performance to include in destination strategies and plans. Having a reliable and valid measure of TXO allows practitioners to include the TXO scale when surveying the market. A deeper understanding of TXO levels in the market and among the customer base allows for better segmentation and increased ability to meet customer needs. As shown, TXO has an effect on many tourist outcomes, and tourism managers are recommended to survey and analyze the effect of TXO on the outcomes that are important for the organization. An example of such an outcome is the propensity to get a travel vaccination, and results show that tourists with higher levels of TXO are more likely to get a vaccine before international travel. Travel agencies may therefore wish to facilitate vaccination for tourists, or alternatively provide extensive information about why vaccination is not necessary in order to alleviate the anxiety of tourists with higher levels of TXO. We found that tourists with higher levels of TXO are less inclined 
to try the local cuisine. Travel agencies can use this insight to include global cuisine options or even dishes from the tourist's home country. For hotels, an implication is that at least a group of tourists is not keen to sample the local cuisine and might for example prefer a global cuisine selection instead. Overall, it is tempting, but dangerous to assume that everyone who travels abroad to another culture are eager to immerse themselves in this new culture.

We also found that higher TXO tourists are more likely to prefer group travel to individual travel. The prevalence of group travel varies across countries. In some countries, such as China, group travel is the norm, while in many Western countries individual travel is the norm. This finding has implications in both cases. Firms in countries where group travel is the norm might wish to be careful when reducing group travel in favor of individual travel because this study shows that some tourists utilize group travel as a way to alleviate foreignness anxiety. In countries where group travel is not the norm, travel agencies, hotels, and other organizations involved in facilitating foreign travel may consider offering group travel options for these higher TXO individuals.

Our findings also indicate that higher TXO individuals are more likely to book travel insurance. The immediate implication is to facilitate booking of travel insurance, and many firms involved in travel facilitation already do this. Overall, the implication is that firms would do well to recognize that some tourists have a tendency toward TXO and as a response the firms can seek to alleviate this foreignness anxiety. Some firms are already intuitively moving in this direction and providing one-click access to travel insurance. However, when firms understand and recognize the underlying phenomenon and reasons, then more opportunities arise, and the sale of insurance is no longer merely an upsell opportunity, but one example of a host of efforts that could provide benefits to customers and increase their satisfaction. Our results further indicate that men score significantly higher on TXO than females, and republican voters score higher than democrat voters. This finding assists 
managers in identifying and targeting this tourist group when designing and communicating travel products.

Like any study, the present study also has certain limitations. Firstly, the study subjects are western tourists. A consequence is that while the present study demonstrates the existence of TXO and its effects on selected outcomes, further studies are needed to investigate whether TXO levels are similar in other cultures, and whether TXO has the same or distinct outcomes across cultural contexts. Secondly, the studies show the status at one point in time. Anecdotal evidence opens up the possibility that TXO levels historically have not been decreasing and perhaps are increasing. While a conceptual argument can be made for the increase of this phenomenon, the present study did not include data from several timeperiods, and therefore cannot present empirical evidence for such a trend. We urge future studies to investigate TXO across time. Thirdly, while TXO is considered a psychological trait, which is relatively stable across situations, the context can still modify the way TXO is expressed and results in tourist behavior. While the present study did not investigate these potential contextual moderators, our study provides fertile ground for studies which seek to further enhance the understanding of the TXO phenomenon and its boundaries. There are other fruitful avenues for future research. For example, TXO may shape interactions between tourists and local service employees or between tourists from different ethnical or cultural backgrounds. Further, if tourists' xenophobia has important ramifications for travel behavior, xenophobia might also play an important role among residents who are constantly faced with incoming foreign tourists. We thus strongly call for research into the role of xenophobia among residents. Indeed, investigating TXO among residents may be crucial to understanding intergroup conflicts in tourism. 


\section{REFERENCES}

Balliet, D., Wu, J., \& De Dreu, C. K. (2014). Ingroup favoritism in cooperation: A meta-analysis. Psychological Bulletin, 140(6), 1556-1581.

Barber, L. K., Barnes, C. M., \& Carlson, K. D. (2013). Random and Systematic Error Effects of Insomnia on Survey Behavior. Organizational Research Methods, 16(4), 616-649.

Brewer, M. B. (1999). The Psychology of Prejudice: Ingroup Love and Outgroup Hate? Journal of Social Issues, 55(3), 429-444.

Chen, N., Hsu, C. H., \& Li, X. R. (2018). Feeling Superior or Deprived? Attitudes and Underlying Mentalities of Residents Towards Mainland Chinese Tourists. Tourism Management, 66, 94-107.

Chen, T., Kalra, A., \& Sun, B. (2009). Why do Consumers Buy Extended Service Contracts? Journal of Consumer Research, 36(4), 611-623.

Chien, P. M., \& Ritchie, B. W. (2018). Understanding Intergroup Conflicts in Tourism. Annals of Tourism Research, forthcoming.

Chien, P. M., Sharifpour, M., Ritchie, B. W., \& Watson, B. (2017). Travelers' Health Risk Perceptions and Protective Behavior: A Psychological Approach. Journal of Travel Research, 56(6), 744-759.

Chang, R. C., Kivela, J., \& Mak, A. H. (2010). Food Preferences of Chinese Tourists. Annals of Tourism Research, 37(4), 989-1011.

Clermont, K. M., \& Eisenberg, T. (2007). Xenophilia or Xenophobia in US Courts? Before and After 9/11. Journal of Empirical Legal Studies, 4(2), 441-464.

Cohen, E., \& Avieli, N. (2004). Food in Tourism: Attraction and Impediment. Annals of Tourism Research, 31(4), 755-778.

Cottrell, C. A., \& Neuberg, S. L. (2005). Different Emotional Reactions to Different Groups: A Sociofunctional Threat-based Approach to "Prejudice". Journal of Personality and Social Psychology, 88(5), 770-789.

Crouch, G. I. (2013). Homo Sapiens on Vacation: What Can We Learn From Darwin? Journal of Travel Research, 52(5), 575-590.

Crowne, D. P. and D. Marlowe. (1960). A New Scale of Social Desirability Independent of Psychopathology. Journal of Consulting Psychology, 24(3), 349-354. 
Crush, Jonathan and Godfrey Tawodzera (2014). Medical Xenophobia and Zimbabwean Migrant Access to Public Health Services in South Africa. Journal of Ethnic and Migration Studies, 40(4), 655-670.

De Freitas, J., \& Cikara, M. (2018). Deep Down my Enemy is Good: Thinking about the True Self reduces Intergroup Bias. Journal of Experimental Social Psychology, 74, 307316.

Dobson, A. P., \& Carter, E. R. (1996). Infectious Diseases and Human Population History. Bioscience, 46, 115-126.

Durante, K. M., \& Griskevicius, V. (2018). Evolution and Consumer Psychology. Consumer Psychology Review, 1(1), 4-21.

Ekinci, Y., \& Hosany, S. (2006). Destination Personality: An Application of Brand Personality to Tourism Destinations. Journal of Travel Research, 45 (2), 127-139.

Faulkner, J., Schaller, M., Park, J. H., \& Duncan, L. A. (2004). Evolved Diseaseavoidance Mechanisms and Contemporary Xenophobic Attitudes. Group Processes \& Intergroup Relations, 7(4), 333-353.

Fornell, C., \& Larcker, D. F. (1981). Evaluating Structural Equation Models with Unobservable Variables and Measurement Error. Journal of Marketing Research, 18(February), 39-50.

Glover, T. D., \& Filep, S. (2015). On Kindness of Strangers in Tourism. Annals of Tourism Research, 50, 159-162.

Goodman, J. K., \& Paolacci, G. (2017). Crowdsourcing Consumer Research. Journal of Consumer Research, 44(1), 196-210.

Griffiths, I., \& Sharpley, R. (2012). Influences of Nationalism on Tourist-host Relationships. Annals of Tourism Research, 39(4), 2051-2072.

Griskevicius, V., \& Kenrick, D. T. (2013). Fundamental Motives: How Evolutionary Needs Influence Consumer Behavior. Journal of Consumer Psychology, 23(3), 372-386.

Hajibaba, H., Gretzel, U., Leisch, F., \& Dolnicar, S. (2015). Crisis-resistant Tourists. Annals of Tourism Research, 53, 46-60.

Halevy, N., Bornstein, G., \& Lilach Sagiv, L. (2008). In-group Love and Out-group Hate as Motives for Individual Participation in Intergroup Conflict: A New Game Paradigm. Psychological Science, 19(4), 405-11. 
Haselton, M. G., \& Nettle, D. (2006). The Paranoid Optimist: An Integrative Evolutionary Model of Cognitive Biases. Personality and Social Psychology Review, 10, 4766.

Hewstone, M., Rubin, M., \& Willis, H. (2002). Intergroup Bias. Annual Review of Psychology, 53, 575-604.

Hinkin, T. R. (1995). A Review of Scale Development Practices in the Study of Organizations. Journal of Management, 21(5), 967-988.

Hjerm, M. (1998). National Identities, National Pride and Xenophobia: A Comparison of Four Western Countries. Acta Sociologica, 41(4), 335-347.

Horn, J. L. (1965). A Rationale and Test for the Number of Factors in Factor Analysis. Psychometrika, 30(2), 179-185.

Jonas, A., Mansfeld, Y., Paz, S., \& Potasman, I. (2011). Determinants of Health Risk Perception among Low-risk-taking Tourists Traveling to Developing Countries. Journal of Travel Research, 50(1), 87-99.

Josiassen, A. (2011). Consumer Disidentification and its Effects on Domestic Product Purchases: An Empirical Investigation in the Netherlands. Journal of Marketing, 75(2), 124140.

Jost, J. T. (2017). The Marketplace of Ideology: "Elective Affinities" in Political Psychology and their Implications for Consumer Behavior. Journal of Consumer Psychology, 27(4), 502-520.

Juvan, E., \& Dolnicar, S. (2014). The Attitude-behaviour Gap in Sustainable Tourism. Annals of Tourism Research, 48, 76-95.

Kim, Y. G., \& Eves, A. (2012). Construction and Validation of a Scale to Measure Tourist Motivation to Consume Local Food. Tourism Management, 33(6), 1458-1467.

Kline, R. B. (2011). Principles and Practice of Structural Equation Modeling. New York: Guilford Press.

Kock, F., Josiassen, A., \& Assaf, A. G. (2016). Advancing Destination Image: The Destination Content Model. Annals of Tourism Research, 61, 28-44.

Kock, F., Josiassen, A., Assaf, A. G., Karpen, I., \& Farrelly, F. (2018a). Tourism Ethnocentrism and its Effects on Tourist and Resident Behavior. Journal of Travel Research, forthcoming.

Kock, F., Josiassen, A., \& Assaf, A. G. (2018b). On the Origin of Tourist Behavior. Annals of Tourism Research, forthcoming. 
Lance, C. E., Butts, M. M., \& Michels, L. C. (2006). The Sources of Four Commonly Reported Cutoff Criteria: What Did They Really Say? Organizational Research Methods, 9(2), 202-220.

Lee, C. K., Song, H. J., Bendle, L. J., Kim, M. J., \& Han, H. (2012). The Impact of Non-pharmaceutical Interventions for 2009 H1N1 Influenza on Travel Intentions: A Model of Goal-directed Behavior. Tourism Management, 33(1), 89-99.

Lepp, A., \& Gibson, H. (2003). Tourist Roles, Perceived Risk and International Tourism. Annals of Tourism Research, 30(3), 606-624.

Mahajan, N., Martinez, M. A., Gutierrez, N. L., Diesendruck, G., Banaji, M. R., \& Santos, L. R. (2011). The Evolution of Intergroup Bias: Perceptions and Attitudes in Rhesus Macaques. Journal of Personality and Social Psychology, 100(3), 387-405.

Mak, A. H., Lumbers, M., \& Eves, A. (2012). Globalisation and Food Consumption in Tourism. Annals of Tourism Research, 39(1), 171-196.

Miss Travel (September 5, 2017). The Biggest Travel Pet Peeves of 2017 [available at: https://www.misstravel.com/blog/biggest-travel-pet-peeves-2017/].

Moliner, M. A., Sánchez, J., Rodríguez, R. M., \& Callarisa, L. (2007). Travel Agency Relationship Quality. Annals of Tourism Research, 34(2), 537-540.

Money, R. B., \& Crotts, J. C. (2003). The Effect of Uncertainty Avoidance on Information Search, Planning, and Purchases of International Travel Vacations. Tourism Management, 24(2), 191-202.

Moran, C., Boley, B. B., Woosnam, K. M., Jordan, E. J., Kline, C., \& Knollenberg, W. (2018). The Battle of the Socials: Which Socially Symbolic Factors Best Predict Intent to Travel? Tourism Management, 68, 324-327.

Navarrete, C. D., \& Fessler, D. M. (2006). Disease Avoidance and Ethnocentrism: The Effects of Disease Vulnerability and Disgust Sensitivity on Intergroup Attitudes. Evolution and Human Behavior, 27(4), 270-282.

Nesse, R. M., \& Williams, G. C. (2012). Why We Get Sick: The New Science of Darwinian Medicine. Vintage.

Ng, S. I., Lee, J. A., \& Soutar, G. N. (2007). Tourists' Intention to Visit a Country: The Impact of Cultural Distance. Tourism Management, 28(6), 1497-1506.

Öhman, A., \& Mineka, S. (2001). Fears, Phobias, and Preparedness: Toward an Evolved Module of Fear and Fear Learning. Psychological Review, 108(3), 483-522. 
Ouellet, J. F. (2007). Consumer Racism and its Effects on Domestic Cross-ethnic Product Purchase: An Empirical Test in the United States, Canada, and France. Journal of Marketing, 71(1), 113-128.

Paas, L. J., Dolnicar, S., \& Karlsson, L. (2018). Instructional Manipulation Checks: A longitudinal analysis with implications for MTurk. International Journal of Research in Marketing, forthcoming.

Pearce, P. L., \& Packer, J. (2013). Minds on the Move: New Links from Psychology to Tourism. Annals of Tourism Research, 40, 386-411.

Pearce, P. L., \& Stringer, P. F. (1991). Psychology and Tourism. Annals of Tourism Research, 18(1), 136-154.

Pinker, S. (2011). The Better Angels of our Nature: The Decline of Violence in History and its Causes. London: Penguin Books.

Podsakoff, P. M., MacKenzie, S. B., \& Podsakoff, N. P. (2012). Sources of Method Bias in Social Science Research and Recommendations on How to Control It. Annual Review of Psychology, 63, 539-569.

Reuters (April 30, 2015). South African Tourism Stung by Anti-immigrant Violence. Reuters, [available at https://uk.reuters.com/article/us-safrica-violence-tourism/south-africantourism-stung-by-anti-immigrant-violence-idUKKBNONLOUQ20150430].

Riek, B. M., Mania, E. W., \& Gaertner, S. L. (2006). Intergroup Threat and Outgroup attitudes: A Meta-analytic Review. Personality and Social Psychology Review, 10(4), 336353.

Rittichainuwat, B. N., \& Chakraborty, G. (2009). Perceived Travel Risks Regarding Terrorism and Disease: The Case of Thailand. Tourism Management, 30(3), 410-418.

Saad, G. (2017). On the Method of Evolutionary Psychology and its Applicability to Consumer Research. Journal of Marketing Research, 54(3), 464-477.

Schaller, M., \& Park, J. H. (2011). The Behavioral Immune System (and Why it Matters). Current Directions in Psychological Science, 20(2), 99-103.

Scheepers, D., Spears, R., Doosje, B., \& Manstead, A. S. (2006). Diversity in In-group Bias: Structural Factors, Situational Features, and Social Functions. Journal of Personality and Social Psychology, 90(6), 944.

Sönmez, S. F., \& Graefe, A. R. (1998). Influence of Terrorism Risk on Foreign Tourism Decisions. Annals of Tourism Research, 25(1), 112-144. 
The Economist (December 12, 2015). The March of Europe's Little Trumps. The Economist, [available at http://www.economist.com].

Thyne, M., Lawson, R., \& Todd, S. (2006). The Use of Conjoint Analysis to Assess the Impact of the Cross-cultural Exchange Between Hosts and Guests. Tourism Management, 27(2), 201-213.

Time Magazine (November 28, 2016). Dictionary.com's 2016 Word of the Year is Xenophobia. Time Magazine, [available at http://www.time.com].

Tinbergen, N. (1963). On Aims and Methods of Ethology. Zeitschrift für Tierpsychologie, 20(4), 410-433.

UNWTO - United Nations World Tourism Organization. 2017. UNWTO Tourism Highlights 2017, [available at: https://www.e-unwto.org/doi/pdf/10.18111/9789284419029].

Voss, K. E., Spangenberg, E. R., \& Grohmann, B. (2003). Measuring the Hedonic and Utilitarian Dimensions of Consumer Attitude. Journal of Marketing Research, 40(3), 310320.

Vugt, M. V., Cremer, D. D., \& Janssen, D. P. (2007). Gender Differences in Cooperation and Competition: The Male-warrior Hypothesis. Psychological Science, 18(1), $19-23$.

Wedeck, H. E. (1929). The Roman Attitude Toward Foreign Influence, Particularly Toward the Greek Influence During the Republic. The Classical Weekly, 195-198.

Weisel, O., \& Böhm, R. (2015). "Ingroup Love” and "Outgroup Hate” in Intergroup Conflict Between Natural Groups. Journal of Experimental Social Psychology, 60, 110-120.

Wolfe, N. D., Dunavan, C. P., \& Diamond, J. (2007). Origins of Major Human Infectious Diseases. Nature, 447, 279-283. 